\title{
Sex differences in HIV-1 viral load and absolute CD4 cell count in long term survivors HIV-1 infected patients from Giurgiu, Romania
}

\author{
Loredana Manolescu $^{1 *}$, Paul Marinescu ${ }^{2}$ \\ 1. Carol Davila University of Medicine and Pharmacy, Bucharest, Romania \\ 2. Public Health Direction, Giurgiu, Romania
}

\begin{abstract}
Introduction: Prior studies assessing sex differences correlated with the levels of human immunodeficiency virus (HIV) RNA and absolute CD4 cell count in adults and children, treated or untreated with antiretroviral (ARV) therapy presented conflicting results. Objective: To assess comparative HIV RNA levels and absolute CD4 cell count in men and women from a large cohort of HIV-infected long term survivors patients. Methods: 462 HIV infected patients were analyzed cross-sectionally and longitudinally after being split into three groups: 156 nä̈ve deceased patients, median age at death 10 years, 197 ARV treated patients, median age 17 years and 109 ARV treated patients, median age 23 years followed up until 2011. HIV RNA and absolute CD4 cell count were measured in all patients enrolled in the study. Results: In cross-sectional analysis of 156 nä̈ve patients HIV RNA median levels were lower in females comparing to males, 4.95 vs. 5.73 HIV RNA log10 (copies/ml). Female absolute CD4 cell count

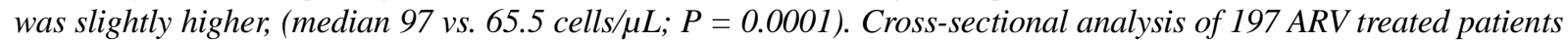
showed a lower log 10 HIV RNA level in females compared to males, $(P=0.0001)$, and also lower median CD4 count values in women, 336 cells/ $\mu L$ vs 456 cells/ $\mu L$ in men, $P=.0001$. Longitudinal analysis revealed statistically significant results: mean log viral loads were lower in females $(F=13.90, P=0.0009)$ and absolute CD4 cell count was lower in malse $(F=16.72, P<0.0001)$, almost across all tested ages. Conclusion: We report steady sex differences in HIV RNA levels and absolute CD4 cell count in ART-treated HIV-infected patients, a fact that may suggest a reevaluation of our current treatment strategies according to sex.
\end{abstract}

Keywords: HIV, sex differences, absolute CD4 cell count, viral load HIV RNA level.

\section{Rezumat}

Introducere. Studiile anterioare care evaluează diferențele în funcție de sex ale încărcăturii virale HIV şi ale numărului absolut de celule CD4 la adulți şi copii tratați sau netratați cu terapie antiretrovirală au prezentat rezultate contradictorii. Obiectiv: Evaluarea comparativă a valorilor incărcăturii virale ARN HIV şi a numărului absolut de celule CD4 la bărbați şi femei, într-un lot de pacienți infectați cu HIV, supraviețuitori de lungă durată. Metode: 462 pacienți infectați cu HIV au fost analizați prin studii transversale şi longitudinale, după împărțirea în trei grupe: 156 pacienți netratați anterior şi decedați, cu vârsta medie la deces 10 ani; 197 pacienți tratați cu antiretrovirale, de vârstă medie 17 ani şi 109 pacienți tratați cu antiretrovirale, de vârstă medie 23 ani,

*Corresponding author: Loredana Manolescu, MD PhD, Carol Davila University of Medicine and Pharmacy, 8 Eroilor Sanitari, Bucharest, Romania.

Tel: 0040723699253; fax:0040214243247; E-mail: manolesculoredana@yahoo.com. 
care au fost monitorizați până în anul 2011. Incărcătura virală ARN HIV şi numărul absolut de celule CD4 au fost determinate la toți pacienții înrolați în studiu. Rezultate: Analiza transversală a celor 156 pacienți netratați anterior a arătat că nivelurile medii ale încărcăturii virale ARN HIV au fost mai mici la femei comparativ cu bărbații, 4.95 vs $5.73 \log 10$ copii/ml. Valoarea numărului absolut de celule CD4 a fost mai mare la femei, (valoare mediană: 97 vs 65.5 celule/ $\mu L, P=0.0001$ ). Analiza transversală a celor 197 pacienți tratați cu aniretrovirale a arătat o diferență de $1 \log 10$ ARN HIV între femei şi bărbați, cu un nivel mai scăzut al încărcăturii virale la femei, $(P=0.0001)$, de asemenea valoarea mediană a numărului de celule CD4 a fost mai scăzută la femei, 336 celule/ $\mu L$ vs 456 celule/ $\mu$ L la bărbați, $P=0.0001$. Analiza longitudinală a arătat rezultate semnificative statistic: valorile mediane ale încărcăturii virale erau mai scăzute la femei $(F=13.90, P=0.0009)$ şi valorile numărului absolut de celule CD4 erau mai scăzute la bărbați $(F=16.72, P<.0001)$, aproape la toate categoriile de vârstă testate. Concluzie: Raportăm diferențe constante în funcție de sex, atât pentru nivelurile încărcăturii virale ARN HIV, cât şi pentru valorile numărului absolut de celule CD4, la pacienții infecțati cu HIV şi tratați cu terapie antiretrovirală, fapt care ar putea sugera o reevaluare a strategiilor actuale de tratament în funcție de sex.

Cuvinte cheie: HIV, numărătoare absolută de celule CD4+, încărcătură virală HIV

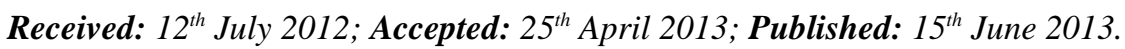

\section{Introduction}

Several cross-sectional and longitudinal studies assessed sex differences correlated with the levels of human immunodeficiency virus (HIV) RNA and absolute CD4 cell count both in adults and children, treated or untreated with antiretroviral (ARV) therapy. In cross-sectional studies women had 0.13-0.35 $\log 10$ (2-fold) lower levels of HIV RNA than do men, despite controlling for CD4 cell count $(1-6)$. In longitudinal studies women had 0.33-0.78 $\log 10$ (2- to 6-fold) lower levels of HIV RNA than do men (7 - 10).

Evidence that HIV-infected women have lower HIV RNA levels and higher CD4cell count comparing to men was attributed to the immunomodulatory effects of sex steroid hormones, such as estrogen and progesterone $(11,12)$. But significant sex differences in HIV RNA levels and CD4 cell count are present in HIV-infected children before the onset of puberty suggesting that intrinsic genetic differences between male and female individuals are unrelated to sex steroid hormone levels and may influence HIV RNA level and CD4 cell count in HIV-infected individuals (13).

In most people infected with HIV, clinical or laboratory evidence of immunodeficiency develops within 10 years of seroconversion, but a few infected people remain healthy for almost a decade. These subjects are termed long-term survivors and they may yield important clues for the study of HIV infection and the development of the acquired immunodeficiency syndrome.

There are 12781 people living with HIV/AIDS in Romania, according to the data provided by Compartment for Monitoring and Evaluation of HIV/AIDS Data, National Institute of Infectious Diseases Prof. Dr. Matei Bals, at 1st of December 2012. Currently, Romania has a large number of survivors, integrated in the 19-24 age group, who belong to the 1987-1990 cohort (>6000). Almost $10 \%$ of them are currently living in the same region, the Giurgiu County (14).

Here we assessed HIV RNA levels and absolute CD4 cell count in a large cohort of HIVinfected patients with an epidemiologic particularity, namely long term survivors, some having experienced multiple therapeutic schemes over time. We undertook a critical epidemiological review of the available evidence concerning whether women have lower levels of human immunodeficiency virus (HIV) RNA than men after several changes in antiretroviral therapy schemes.

\section{Methods}

This research was approved by the ethical review board of the Infectious Disease Hospital from Giurgiu County. 


\section{Study participants}

Data from an initial large cohort of 462 HIV infected individuals from Giurgiu County, Romania was analyzed at different points in time. These patients were born in poor families or abandoned in foster care between 1987 to 1990 and were probably infected in the same way and probably at the same period of time by horizontal route. The majority of patients were HIV diagnosed from 1989 to 1999 but there were 35 patients that were diagnosed later, between 2000 and 2005. The patients were clinically evaluated in day clinic at Giurgiu Infectious Disease Hospital. Many of these patients have begun therapy since 1995 and have experimented between two and five antiretroviral regimens until the end of 2011.

First CD4 and (HIV) RNA evaluations were performed in 1995 for those already diagnosed who started antiretroviral (ARV) therapy at that time. Patients diagnosed after 1995 have been evaluated at the time of HIV diagnosis and if eligible they started ARV therapy. As ARV drugs developed worldwide, they were administered to Romanian patients so their ARV therapy changed along with the improvement of those drugs and according to the need of the patients. From the initial group $33.76 \%$ patients died until 2005. About $42.56 \%$ of patients were lost from hospital evidence until the end of 2011. For the remaining $23.59 \%$ of patients, monitoring of CD4 and HIV RNA was performed until the end of 2011.

\section{Quantitative CD4 and HIV RNA}

HIV RNA and absolute CD4 cell count were measured in all the participants enrolled in the study. Absolute CD4 cell count was performed at least twice a year and HIV RNA once a year starting with 1995 until present.

From 1995 until 2005 absolute CD4 cell count was determined from fresh whole blood samples on a 3-color flow cytometer. Plasma HIV RNA levels were measured from fresh blood specimens using the Roche Amplicor, version 1.5 (dynamic range, 400-750 000 copies $/ \mathrm{mL}$ ).
Starting with 2005, absolute CD4 cell count was determined from fresh whole blood samples on a 4-color flow cytometer. Plasma HIV RNA levels were measured from fresh blood specimens using the COBAS AmpliPrep/COBAS TaqMan HIV-1 Test (dynamic range, 20-10 000000 copies $/ \mathrm{mL}$ ). The tests were conducted in Professor Dr. Victor Babes Infectious Diseases Hospital from Bucharest. Because the dynamic ranges of these assays differed, for combined analyses we assigned all HIV RNA measurements > 500000 copies $/ \mathrm{mL}$ as a value of 500001 copies $/ \mathrm{mL}$, and we assigned measurements $<400$ copies $/ \mathrm{mL}$ as a value of 399 copies $/ \mathrm{mL}$. Log-transformed HIV RNA levels were used for all analyses.

\section{Statistical analyses}

Differences in HIV RNA levels and absolute CD4 cell count was evaluated by Fisher's exact test analysis of contingency tables, using GraphPad QuickCalcs (http://www.graphpad.com/quickcalcs/index.cfm ). Two-tailed P values were reported. $\mathrm{P}<.05$ was considered statistically significant. Median values were compared using the Mann-Whitney Wilcoxon match-pairs signed rank test. Median values were used in all tables due to the fact that they are less affected by the presence of an outlier and are better and more reliable measures of central tendency. Linear regression models were developed with GraphPad Prism 5.0. Linear regression lines showing the relationship of absolute CD4 levels (cells $/ \mu \mathrm{L}$ ) to age in male and female patients followed longitudinally in group three and linear regression lines showing the relationship of mean HIV RNA levels $(\log 10$ copies $/ \mathrm{mL})$ to age in male and female patients followed longitudinally in group three were developed.

Analyses of baseline characteristics were performed with either a $t$ test for categorical variables or an $\mathrm{F}$ test for continuous variables, to determine whether there were gender differences at baseline. These analyses were performed separately for the three groups, namely, HIV-infected naive children from 
Table 1. Cohort characteristics

\begin{tabular}{lcccc}
\hline Number of patients & $\begin{array}{c}\text { Total of patients } \\
\mathbf{n = 4 6 2}\end{array}$ & $\begin{array}{c}\text { Deceased } \\
\mathbf{A R V} \text { nä̈ve } \\
\mathbf{n = 1 5 6}\end{array}$ & $\begin{array}{c}\text { Lost from evidence } \\
\text { ARV treated } \\
\mathbf{n}=\mathbf{1 9 7}\end{array}$ & $\begin{array}{c}\text { ARV treated } \\
\mathbf{n = 1 0 9}\end{array}$ \\
\hline Females & $231(50 \%)$ & $58(37.17 \%)$ & $112(56.85 \%)$ & $61(55.96 \%)$ \\
Age $($ years) & $17(7-24)$ & $10(7-16)$ & $17(15-18)$ & $23(21-24)$ \\
Follow up period & $1995-2011$ & $1995-2005$ & $1995-2005$ & $1995-2011$ \\
HIV diagnose date & $1989-2005$ & $1989-2001$ & $1989-2005$ & $1989-2003$ \\
CD4 count (cells/ $\mu \mathrm{L})_{\mathrm{a}}$ & $242(0-1652)$ & $73(0-1040)$ & $379(5-1652)$ & $495.5(3-1250)$ \\
HIV RNA Level Log 10 & $3.31(2.6-5.7)$ & $5.5(3.5-5.7)$ & $2.9(2.6-5.7)$ & $2.6(2.6-5.01)$ \\
(copies/ml) $^{\text {ab }}$ & & &
\end{tabular}

Values are medians (limits) unless otherwise listed. ${ }^{\text {a }} \mathrm{P}<0.0001$ by Fisher's and chi-square test. ${ }^{\mathrm{b}} \log 10$ (copies/mL): values truncated the narrowest dynamic range of 2.6-5.7.

group one, patients treated with ART from group two and ARV treated patients continuously followed over time from group three.

\section{Results}

\section{Cohort Characteristics}

The total of 462 analyzed HIV infected patients was split into three groups. Group one, 156 deceased patients, median age at death 10 years (limits 7-16) were patients not treated with any ARV regimen. The second group, 197 patients, median age at last investigation 17 years (limits 15-18) was composed by patients followed up only until 2005 due to several reasons such as: change of residence, lack of adherence or enrollment in other AIDS centers. The third group, 109 patients, median age at last investigation 23 years (limits 21-24), were followed up until the end of 2011 (Table 1). All laboratory investigations presented in Table 1 are from their last visit in Giurgiu Day Clinic.

The initial cohort was balanced with regard to sex but differed substantially with regard to the level of immune status and age. In the deceased group the majority, $62.87 \%$ were male participants.

\section{Sex differences in HIV RNA levels}

In cross-sectional analysis of the 156 deceased patients, HIV RNA median levels were lower in females than in males - 4.95 HIV RNA lo- $\mathrm{g}_{10}$ (copies/ml) vs. 5.73 HIV RNA $\log _{10}$ (copies $/ \mathrm{ml}$ ). Median HIV RNA values were analyzed with the non-parametric Mann-Whitney Wilcoxon test which showed no statistical significance; (two tailed $\mathrm{P}$ value $=0.3458)$ (Table 2). No association could be found between CD4 count, HIV RNA levels and age at these patients.

In the cross-sectional analysis of the 197 patients which were ARV treated but lost from evidence there were no differences regarding the age (Table3) and number of ARV regimens that correlate with sex of the patients. These patients, irrespective of gender, had two ARV regimens until they were lost from evidence. Female gender presented lower HIV RNA level with one $\log _{10}$ than male gender and the difference was statistically significant (two tailed $P$ value $=0.0001$ ).

When stratifying by CD4 count (Table 4) the female participants maintained lower HIVRNA level for all immunity groups and in the immunosupressed group the difference was statistically significant, $3.7 \log _{10}$ (copies/ml) in females vs. $4.5 \log _{10}$ (copies $/ \mathrm{ml}$ ) in males.

\section{Sex differences in CD4 cell count}

In the cross-sectional analysis of the 156 deceased patients, absolute CD4 cell count was a little bit higher in females than males and reached statistical significance, (median 97 vs. 65.5 cells $/ \mu \mathrm{L}$; $\mathrm{P}=0.0001$ ), Table 2. Surprisingly, patients with CD4 level $>500$ cells $/ \mu$ L presented statistically sig- 
Table 2. Age, CD4 Count and HIV RNA level by sex in 156 deceased patients

\begin{tabular}{lccc}
\hline Deceased patients & Females & Males & P value \\
\hline $\mathrm{n}$ & 58 & 98 & \\
Age $($ years $)$ & $10(7-16)$ & $10(7-15)$ & 0.3307 \\
CD4 count (cells/ $\mu \mathrm{L})$ & $97(11-774)$ & $65.5(50-1040)$ & 0.0001 \\
$\begin{array}{l}\text { HIV RNA Level Log } \\
\text { (copies/ml) }\end{array}$ & $4.95(4.7-5.1)$ & $5.73(3.5-5.8)$ & 0.3458 \\
\hline
\end{tabular}

Table 3. Age, CD4 Count and HIV RNA level by sex in 197 ARV treated patients

\begin{tabular}{lccc}
\hline Patients lost from evidence & Females & Males & P value \\
\hline $\mathrm{n}$ & 112 & 85 & \\
Age $($ years $)$ & $17(15-18)$ & $17(15-18)$ & 0.3307 \\
CD4 count (cells/ $\mu \mathrm{L})$ & $336(5-1652)$ & $456(7-1632)$ & 0.0001 \\
HIV RNA Level Log & $2.6(2.6-5.7)$ & $3.6(2.6-5.7)$ & 0.0001 \\
(copies/ml) & & \\
\hline
\end{tabular}

Table 4. CD4 cell count by HIV RNA level

\begin{tabular}{|c|c|c|c|}
\hline \multirow{2}{*}{$\begin{array}{l}\text { HIV RNA Level } \\
\text { Log }_{10}(\text { copies/ml) }\end{array}$} & \multirow{2}{*}{$\mathbf{n}$} & \multicolumn{2}{|c|}{ CD4 count $($ cells $/ \mu L)$} \\
\hline & & female & male \\
\hline$<4$ & 155 & $461(5-1652)$ & $384(7-1632)$ \\
\hline $4-5$ & 28 & $227.5(86-547)$ & $274(50-600)$ \\
\hline$>5$ & 14 & $50(7-426)$ & $418(380-456)$ \\
\hline $\begin{array}{l}\text { CD4 count } \\
(\text { cells } / \mu \mathrm{L})\end{array}$ & & \multicolumn{2}{|c|}{$\begin{array}{c}\text { HIV RNA Level Log } \\
\text { (copies/ml) }\end{array}$} \\
\hline$<200$ & 59 & $3.7(2.6-5.7)$ & $4.5(2.6-5.7)$ \\
\hline $200-500$ & 67 & $3.5(2.6-5.7)$ & $4.1(2.6-5.4)$ \\
\hline$>500$ & 71 & $2.6(2.6-5.2)$ & $2.8(2.6-5.7)$ \\
\hline
\end{tabular}

${ }^{\mathrm{a}} \mathrm{P}<.0001$ by Fisher's and chi-square test.

NOTE. Values are medians (limits) unless otherwise listed. there was a pronounced sex difference in absolute CD4 cell count among patients with HIV RNA levels $>5 \log _{10}$ (copies $/ \mathrm{ml}$ ), females had statistically significant lower values for absolute CD4 cell count than males $(50$ cells $/ \mu \mathrm{L}$ vs. 418 cells $/ \mu \mathrm{L}, \mathrm{P}<0.0001)$ (Table 4).

\section{Longitudinal analysis}

Because CD4 cell count serves as a limited surrogate for disease stage, longitudinal studies allow comparisons between sex groups while controlling for the duration of infection. To further evaluate the effect of sex on age-related changes in HIV RNA level, a linear regression model using longitudinal data from group three was developed. A total of 109 HIV infected patients 23 years, median age at the end of 2011, were retrospectively followed up for their HIV RNA level and absolute CD4 cell count over a period of seventeen years. All this time the patients were heavily ARV treated, the median number of ARV regimens was 3 (limits: 2-5 regimens). HIV RNA level and absolute CD4 cell count were determined by regular basis follow up once a year, median number of evaluation was 9 (range, 3-13). We found that mean log viral loads were lower for female gender and higher for male gender almost across nificant higher CD4 values in males vs. females, (median values 725 vs. 657 cells $/ \mu \mathrm{L}, \mathrm{P}<0.0001$ ). There was no statistical difference in absolute CD4 cell count when stratifying by age group.

In the cross-sectional analysis of the 197 patients which were ARV treated but lost from evidence, CD4 median values of male participants were higher: 456 cells $/ \mu \mathrm{L}$ vs. 336 cells $/ \mu \mathrm{L}$ in females (two tailed $\mathrm{P}$ value = 0.0001). When stratifying by HIV RNA level, all ages tested and followed a common slope pattern $(\mathrm{F}=0.265, \mathrm{P}=0.6102)$ (Figure 1). The differences between sexes were extremely significant $(\mathrm{F}=13.90, \mathrm{P}=0.0009)$ showing a variation of more than $2 \log _{10}$ for male participants, mean difference $0.9 \log _{10}$ copies/ml, (limits: $0.23-2.1 \log _{10}$ copies $/ \mathrm{ml}$ ). Linear regression analysis of absolute CD4 cell count similarly showed an extremely significant difference between sexes $(\mathrm{F}=16.72$, $\mathrm{P}<0.0001$ ), female patients had higher absolute 


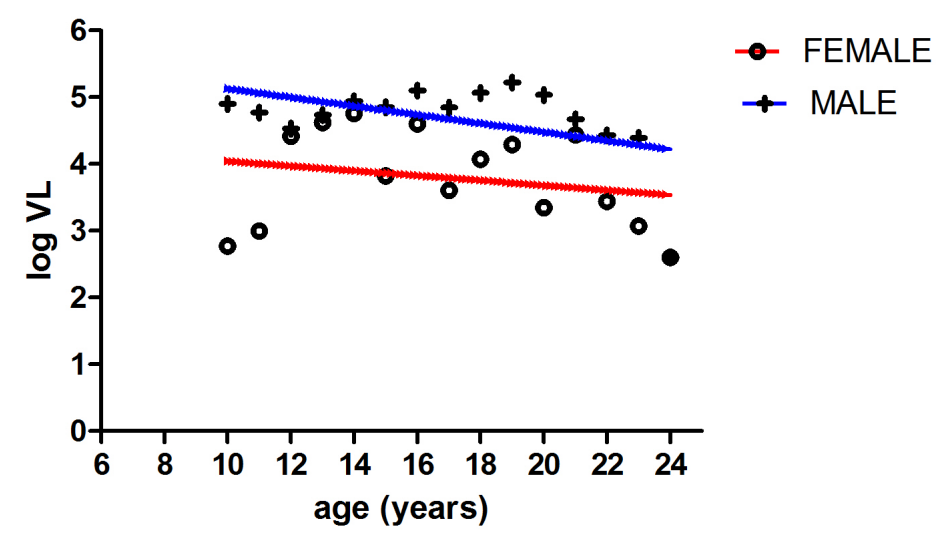

Figure1. Relationship of mean HIV RNA levels $(\log 10$ copies/mL) with age in male and female patients followed longitudinally in group three. HIV RNA levels were lower in female participants across all observed ages.

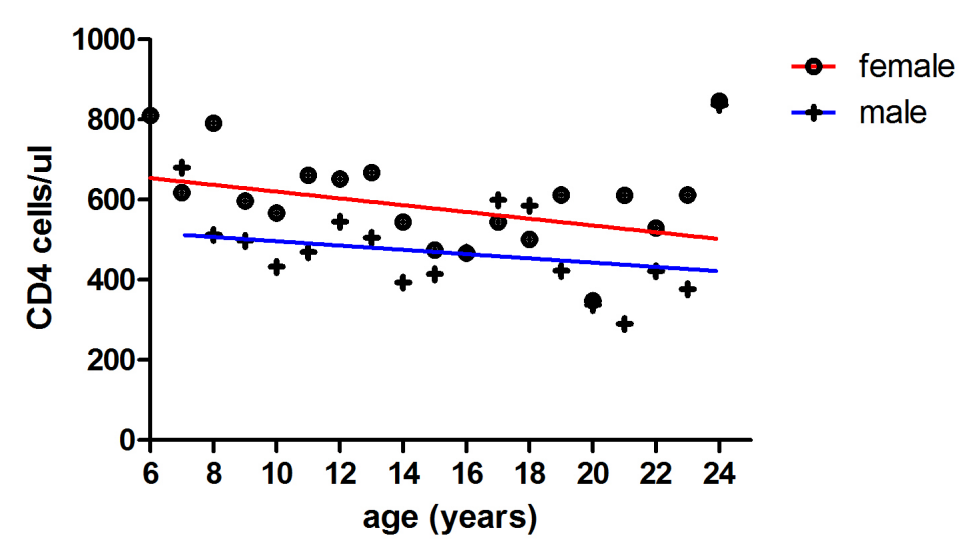

Figure 2. Relationship of absolute CD4 levels (cells/ $\mu \mathrm{L}$ ) with age in male and female patients followed longitudinally in group three. Absolute CD4 count was higher among female participants across all observed ages.

CD4 cell count mean difference 103 cells $/ \mu \mathrm{L}$, (limits: 9-321 CD4 cells/ $\mu \mathrm{L}$ ) across all tested ages (Figure 2).

\section{Discussion}

Even if nowadays in our country and throughout Eastern Europe we have access to high standard tests such as sequencing and genotyping and when starting or changing ARV therapy we take into account resistance mutations or transmitted drug resistance, we must never forget the importance of two simple tests: viral load - HIV RNA levels and absolute CD4 cell count, tests that remain the key laboratory measures used to guide initiation and monitoring of ART. Here we analyzed the differences between these tests according to gender on a unitary cohort of subjects within the same interval of age considered to be long term survivors, revealing that differences in HIV viral load and absolute CD4 cell count between male and female individuals are evident and steady from childhood to adult age.

A recent study (13) found substantial differences in HIV RNA level and CD4 cell percentages between naive HIV-infected boys and girls throughout childhood and before the onset of puberty suggesting that sex hormones are unlikely to be the major driver of the sex disparity in HIV RNA levels.

Prior studies on ARV treated HIV infected individuals clearly established sex differences in HIV RNA levels and CD4 cell parameters among adults but have also presented conflicting results $(15,16)$. There is one study of 158 children receiving ART that found HIV RNA levels to be $0.38 \log$ lower in girls than in boys but found no difference in CD4 cell count or percentage (15). But there are few studies that analyzed differences on HIV RNA level and CD4 cell count in a large number of participants and none over such a long period of time.

For our study we drew data from a large cohort of children, a total of 462 HIV infected pa- 
tients analyzed into three groups. $33.76 \%$ of the patients were naïve to ARV and 66.23 were ARV experimented. Out of the treated patients $30.62 \%$ patients were longitudinally followed up for more than seventeen years. Our cohort is representative because the participants are from the same region, are infected in the same way and were subjected to the same behavioral and epidemiologic risk factors or socioeconomic disparities. The majority of patients came from HIV/AIDS uninfected parents.

Our patients clearly present lower HIV RNA levels in female comparing to male participants in all groups, ARV naïve or treated and by all types of analysis: cross-sectional and longitudinal. Regarding the absolute CD4 cells count, in cross sectional analysis, the levels of CD4 cells were for females slightly elevated in ARV naïve patients group and lower in ARV treated patients group. In longitudinal analysis the difference between sexes was evident and statistical significant: female participants presented higher absolute CD4 cell count levels.

Current World Health Organization (WHO) Pediatric HIV Treatment Guidelines (17) states that viral load is the most sensitive way to detect viral replication. Virological failure is recognized if the child is adherent to their (first-line) ART regimen, more than 24 weeks from initiation of ART, and has a persistent viral load over 5000 copies/ml. A delay in switching therapy in a child with high levels of viral replication may lead to greater development of resistance and compromise the virological activity of standard second-line regimens. In our longitudinal analysis of viral load girls of 10 and 11 years old presented more than 2 log10 lower HIV RNA levels than boys at the same age.

Because the differences in HIV RNA levels according to sex occurred over a sustained period in time, seventeen years, but were higher in early ages, a change toward the viral threshold for initiation and change of therapy in female children may be considered, with research that shows therapy to be most beneficial when started early.
Also under treatment on this segment of population must be taken into account.

In resource-limitedsettings it may not be feasible to perform viral load testing very often. The absolute CD4 count may be an alternative used to evaluate and choose the moment of therapy change. Differences between genders with regard to this parameter must be considered.

This study has several limitations. HIV RNA levels were truncated at $5.7 \log$ copies $/ \mathrm{mL}$, limiting the ability to accurately quantify the effect size of sex at high HIV RNA levels. But the fact that sex differences were stable over time in the longitudinal data analysis makes the influence of such bias less likely. Another potential limitation of this study is that data were combined from 3 groups that differed by age, stage of disease, and HIV RNA assay used; however, each group was balanced with regard to sex, and inclusion in the linear model did not alter the results.

\section{Conclusions}

We report steady sex differences in plasma HIV RNA levels and absolute CD4 cell count between ART-treated with potent combination therapy, HIV-infected, female and male participants. This result is in partially agreement with previous published studies but was never revealed for this segment of age and for such a long time followed up period. The follow up period covers childhood and teenage. This findings may have implications in understanding sex differences in ARV experimented HIV infected patients and suggest a reevaluation of our current treatment strategies according to sex.

\section{Declaration of competing interests}

The authors declare that they have no competing interests.

\section{Authors' contributions}

All authors contributed to study design, data interpretation and critical revision of the manuscript. 


\section{Acknowledgement}

The authors acknowledge the medical staff from Infectious Disease Hospital from Giurgiu County and the staff from Sfanta Maria Foundation for providing the patients' charts.

\section{References}

1. Anastos K, Gange SJ, Lau B, Weiser B, Detels R, Giorgi JV et al. Association of race and gender with HIV1 RNA levels and immunologic progression. J Acquir Immune Defic Syndr 2000; (24):218-26.

2. Rezza G, Lepri AC, d'Arminio Monforte A, Pezzotti P, Castelli F, Dianzani F et al. Plasma viral load concentrations in women and men from different exposure categories and with known duration of HIV infection. ICONA Study Group. J Acquir Immune Defic Syndr 2000; (25):56-62.

3. Kalish LA, Collier AC, Flanigan TP, Kumar PN. Plasma human immunodeficiency virus (HIV) type 1 RNA load in men and women with advanced HIV-1 disease. J Infect Dis 2000; (182):603-6.

4. Moroni M. Sex differences in HIV-1 viral load and progression to AIDS: ICONA Study Group. Italian cohort of HIV-1 positive individuals [letter; comment]. Lancet 1999; (353):589-90.

5. Moore R, Cheever L, Keruly J, Chaisson R. Lack of sex difference in CD4 to HIV-1 RNA viral load ratio. Lancet 1999; (353):463-4.

6. Junghans C, Ledergerber B, Chan P, Weber R, Egger $M$. Sex differences in HIV-1 viral load and progression to AIDS. Lancet 1999; (353):589.

7. Lyles C, Dorrucci M, Vlahov D, Pezzotti P, Angarano G, Sinicco A et al. Longitudinal human immunodeficiency virus type 1 load in the Italian Seroconversion Study: correlates and temporal trends of virus load. J Infect Dis 1999; (180): 1018-24.
8. Sterling T, Lyles C, Vlahov D, Astemborski J, Margolick J, Quinn T.Sex differences in longitudinal human immunodeficiency virus type 1 RNA levels among seroconverters. J Infect Dis 1999; (180):666-72.

9. Evans JS, Nims T, Cooley J, Bradley W, Jagodzinski $\mathrm{L}$, Zhou $\mathrm{S}$ et al. Serum levels of virus burden in earlystage human immunodeficiency virus type 1 disease in women. J Infect Dis 1997; (175):795-800.

10. Sterling TR, Vlahov D, Astemborski J, Hoover DR, Margolick JB, Quinn TC. Initial plasma HIV-1 RNA levels and progression to AIDS in women and men. N Engl J Med 2001; (344):720-5.

11. Fish EN. The X-files in immunity: sex-based differences predispose immune responses. Nat Rev Immunol 2008; (8):737-744.

12. Bouman A, Heineman MJ, Faas MM. Sex hormones and the immune response in humans. Hum Reprod Update 2005; (11):411-423.

13. Ruel TD, Zanoni BC, Ssewanyana I, Cao H, Havlir DV, Kamya M, et al. Sex differences in HIV RNA level and CD4 cell percentage during childhood. Clin. Infect. Dis. 2011 Sep;53(6):592-9.

14. CNLAS. Comisia Nationala de Lupta Anti Sida. Report on HIV/AIDS infection at the 1st December 2012.http://www.cnlas.ro/date-statistice/ (accesed at 4th April 2013)

15. Foca M, Moye J, Chu C, Matthews Y, Rich K, Handelsman $\mathrm{E}$ et al. Gender differences in lymphocyte populations, plasma HIV RNA levels, and disease progression in a cohort of children born to women infected with HIV. Pediatrics 2006; (118):146-155.

16. European Collaborative Study. Are there gender and race differences in cellular immunity patterns over age in infected and uninfected children born to HIV-infected women? J Acquir Immune Defic Syndr 2003; (33):635-641. 17. Antiretroviral Therapy for HIV Infection in Infants and Children: towards universal access. Recommendations for a public health approach, WHO Library Cataloguing, Austria, 2010, WHO, Chapter 11. First-line regimen treatment failure; When to switch regimens - Principles, 50. 